'Under the Mediterranean' The Honor Frost Foundation Conference on Mediterranean Maritime Archaeology $20_{\text {th }}-23_{\text {rd }}$ October 2017 Short Report Series.

doi: https://doi.org/10.33583/utm2020.02

(C) 2020 The Author

\title{
The Ma'agan Mikhael B Shipwreck: Preliminary report
}

\section{Cohen, M. Creisher}

Department of Maritime Civilizations and the Leon Recanati Institute for Maritime Studies, University of Haifa, Haifa 3498838, Israel.

The Ma'agan Mikhael B shipwreck lies at a depth of $2 \mathrm{~m}$ of water, buried under $1.5 \mathrm{~m}$ of sand off the Mediterranean coast of Israel. The archaeological remains exposed are in a good state of preservation, and comprise endposts, aprons, framing timbers, hull planks, stringers and bulkheads. The various finds include rigging elements, organic finds and ceramic ware. Preliminary dating was corroborated by ${ }_{14} \mathrm{C}$ AMS analyses of wood and organic samples to the 7th-9th century AD: the late Byzantine-early Islamic period in the region. This study aims to evaluate its significance in the period of transition in ship construction from 'shell-first' to 'frame-first'.

\section{Key words}

Late Antiquity, Mediterranean, ship construction, shipwreck, transition in construction.

The Ma'agan Mikhael B shipwreck was discovered in 2005 by two divers returning from a recreational dive, who reported seeing framing timbers, ceramic sherds and stones. It is located about $150 \mathrm{~m}$ south of the $400 \mathrm{BC}$ Ma'agan Mikhael shipwreck, discovered in 1985, 70 m off the Mediterranean coast of Israel (Linder, 2003; Kahanov, 2011). In May 2015, this information was verified by a sub-bottom profiler survey conducted by Dr Deborah Cvikel of the University of Haifa and Drs Ole Grøn and Lars Ole Boldreel of the University of Denmark. In August 2015, a water-jetting survey exposed fragments of wood, a coil of rope $18 \mathrm{~cm}$ long, and a pine cone (Cvikel et al., 2017). 
Preliminary dating was obtained by ${ }_{14} \mathrm{C}$ AMS analyses of wood and organic samples to the 7 th-9th centuries $\mathrm{AD}$, which is the late Byzantine-early Islamic period in the region. Typological studies of the amphorae have identified at least four different types of transport vessels - Late Roman Amphora Types 1, 2, 4 and 5. The dates of the amphorae and other ceramics correspond to the earlier part of the ${ }_{14} \mathrm{C}$ date range.

The second half of the 1st millennium AD witnessed a change in Mediterranean shipbuilding techniques. Until about a decade ago it was widely accepted that the first ship found of pure frame-based construction was the Serçe Limanı dated to 1025 AD. However, the Byzantine and Islamic period shipwrecks at Dor/Tantura lagoon have provided evidence of earlier frame-based ships. This process of transition has been one of the main issues in the history of shipbuilding for over 70 years; and many questions still remain unanswered (Pomey et al., 2012). The dating of the Ma'agan Mikhael B shipwreck was an excellent reason to excavate it, in order to evaluate the technological significance of its construction in the period of transition in ship construction from 'shell-first' to 'frame-based'.

\section{The underwater excavations}

A long-term programme of underwater excavation and research of the Ma'agan Mikhael B shipwreck was initiated in 2016. Three seasons of underwater excavations were conducted in May and December 2016 and September 2017 by the Leon Recanati Institute for Maritime Studies of the University of Haifa. The site's location is challenging due to a small island which creates a meeting point between the offshore (south-west) current and a local, north-west current and a disturbed sea. Inclement weather allowed only a few working days in the first two seasons. However, during the third season 500 dives were made in eight working days (Fig. 1).

The shipwreck is $19.6 \mathrm{~m}$ long between extremities, and a maximum $4.9 \mathrm{~m}$ wide. The remains are oriented roughly east-west. The maximum depth that was reached was $2.2 \mathrm{~m}$, and the keelson and keel have not yet been exposed. Among the hull remains, which are well preserved, are endposts, aprons, framing timbers, hull planks, stringers and bulkheads. 


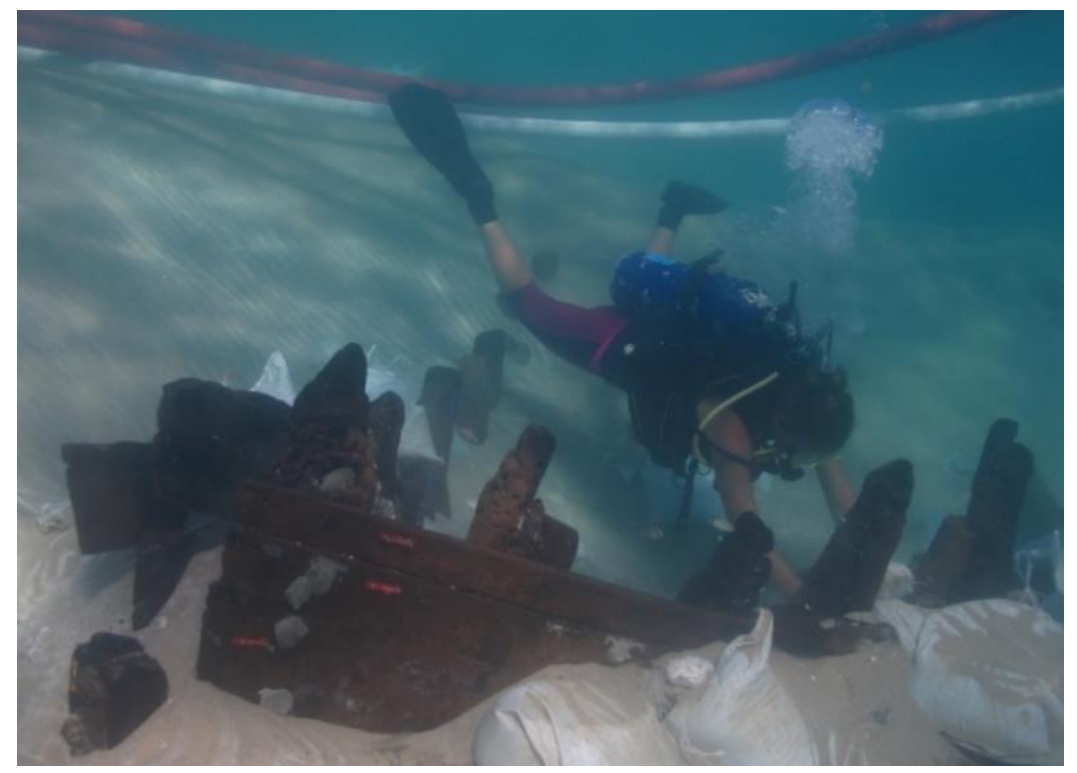

Fig. 1: A diver excavating the western side of the Ma'agan Mikhael B's hull (Photo: A. Yurman)

\section{The hull remains}

\section{The endposts}

The eastern endpost is composed of two timbers connected by an elaborate (similar to Jupiter) scarf, an example of which was found in the Tantura F ship (Barkai and Kahanov, 2016: 8). The upper timber was made of pine (Pinus halepensis or Pinus brutia), and the lower timber was walnut (Juglans regia). The overall exposed length of the endpost is $90 \mathrm{~cm}$. At this point in the research it is not possible to determine which end was the bow and which the stern.

\section{The aprons}

Aprons were installed next to each endpost, and both were made of walnut (Juglans regia). The western apron was exposed to a length of $49 \mathrm{~cm}$, and it seems to be almost round, with a diameter of about $8 \mathrm{~cm}$. The eastern apron was exposed to a length of approximately $40 \mathrm{~cm}$. Its dimensions are $24 \mathrm{~cm}$ sided and $22 \mathrm{~cm}$ moulded.

\section{The framing timbers}

Fifty-six framing timbers were exposed on the southern side of the hull remains, and 63 on the northern side. The cross-sections of the timbers vary: some have a round cross-section, others are trapezoidal or rectangular. Overlapping faces of adjacent frames were worked smooth.

Of the 25 sampled framing timbers, 24 were made of walnut (Juglans regia) and one made of oak (Quercus ilex). It is suggested that the origin of the walnut was the western or northern part of the Aegean Sea. On some of the framing timbers sealing material and tool marks, perhaps of an adze, are visible. The framing timbers were exposed to a length of about $1 \mathrm{~m}$, and it was noticeable that the moulded dimension increased with depth. The framing timbers were $12 \mathrm{~cm}$ sided and moulded, with an average room and space of $44 \mathrm{~cm}$. 


\section{The hull planks}

Ten hull planks were exposed and documented on the southern side of the shipwreck, and two on the northern side. The planks were made of fir (Abies sp.). Many of the planks have scorch marks on their inner side, which might indicate bending through a heating process, known as 'char-bending' (Greenhill, 1957: 115; de Zeeuw, 1967: 154). The planks were about $3 \mathrm{~cm}$ thick. Joints between planks have not yet been detected, so it is impossible to suggest how strakes were put together.

The stringers

Stringers were found on the north and south-eastern sides of the hull; providing it with longitudinal reinforcement (Steffy, 1994: 269). The maximum length measured was $4.94 \mathrm{~m}$, but these timbers continue well into the sand or are broken. They were on average $18.3 \mathrm{~cm}$ wide and $10.1 \mathrm{~cm}$ thick. They were nailed to the frames from the inside using metal, apparently iron, fastenings. Inscribed in the southern clamp are what seem to be the two Greek letters $\Pi(\mathrm{Pi})$ and $\mathrm{M}(\mathrm{Mu})$ - perhaps carpenters' marks, or initials of the shipwrights or crew members.

\section{The bulkheads}

There are two transverse sets of vertical planks inside the hull, most probably bulkheads. The eastern and western bulkheads are located $13.8 \mathrm{~m}$ and $5.5 \mathrm{~m}$ from the western apron respectively. They were exposed to a maximum length of $54 \mathrm{~cm}$, but are certainly longer. The planks are typically $15 \mathrm{~cm}$ wide and $4 \mathrm{~cm}$ thick. The bulkheads created separate compartments in the hull (Steffy, 1994: 268): the cargo hold and equipment storage spaces at bow and stern.

\section{Fastenings}

The appearance of concretions, and the fact that very little of the metal survived, indicate the use of iron nails. Square cross-section nail holes with imprints of round heads can be seen in the hull planks. The average diameter of the nails connecting the hull planks to the framing timbers is $4 \mathrm{~mm}$, with the head diameter of $16 \mathrm{~mm}$. Two nails were used to connect each plank to frames. On the inner face of the frames are indications of nails of 9 $\mathrm{mm}$ square cross-section for fastening the ceiling planks, and of concretions. At this point in the research no evidence of edge-fastening has been detected.

\section{The finds}

Various finds included rigging elements, organic finds, ceramic sherds and complete amphorae. The finds were documented on site, retrieved, registered, and are undergoing study.

\section{Rigging elements}

Two blocks were found amidships. They were similar in size: $35 \mathrm{~cm}$ long and $10 \mathrm{~cm}$ wide. Both comprised a single sheave and contained remains of rope. Several pieces of ropes of various diameters were found. These 
included a coil of rope about $18 \mathrm{~cm}$ long and about $35 \mathrm{~mm}$ in diameter. Further study is needed in order to understand the function of these items, and to gain an understanding of the rigging of the ship.

\section{Organic finds}

The organic finds can be divided into two groups: artefacts (the remains of a woven basket and a leather sack) and food remains. The food remains may hint at various aspects of daily life aboard a ship of this period. Well preserved olive pits, grape seeds, peach and carob stones, and different kinds of nuts were found. Dried fruits were usually pitted; hence the stones most probably came from fresh fruit (Ward, 2004: 501). The olives were identified as Nabali, which were common in the central mountains of Israel at this time, mostly known pickled. It is reasonable to suggest that at least some of the remains were part of the crew's food supply.

\section{Ceramic ware}

During the excavations, 28 amphorae were identified inside the ship and documented, in addition to many ceramic sherds. One cooking pot lid, three bowls of different sizes with roulette decoration, and bricks were also found. Typological studies of the amphorae have identified at least four types, including Late Roman Amphora Types 1, 2, 4 and 5. Some of them had dipinto decoration, and at least one bore a Greek inscription on the shoulder.

\section{Comparative study}

Although the measurements of the Ma'agan Mikhael B ship are preliminary, it is important to compare them to other shipwrecks of the period (Table 1). The surviving length of the Ma'agan Mikhael B shipwreck is $19.6 \mathrm{~m}$. This is larger than the original length of Dor 2001/1, St Gervais 2, Dor 2006, Yassiada I, Tantura F, Tantura E, Tantura B and Bozburun.

Naturally, the width of the planks depends on their place in the hull. Since the planks were only partially exposed, these measurements are likely to change as the research progresses. However, similar thicknesses occur in the Dor 2006, St. Gervais 2, Dor 2006 and Tantura B shipwrecks.

At present it is difficult to deduce much from the frame dimensions. However, it is interesting that the sided and moulded dimensions vary between these shipwrecks. The room and space is larger than that of the nine other shipwrecks of that period, but this could be due to the fact that the measurements were taken far from the keelson. 
Table 1: Comparative study

\begin{tabular}{|c|c|c|c|c|}
\hline Vessel & $\begin{array}{c}\text { Date (Century, } \\
\text { AD) }\end{array}$ & $\begin{array}{l}\text { Suggested } \\
\text { length } \\
\text { (m) }\end{array}$ & $\begin{array}{c}\text { Planks: } \\
\text { width, thickness (cm) }\end{array}$ & $\begin{array}{c}\text { Frames: } \\
\text { sided, moulded, } \\
\text { room \& space }(\mathbf{c m})\end{array}$ \\
\hline Dor 2001/1 & $\begin{array}{c}\text { First third of } \\
\text { 6th }\end{array}$ & 16.9 & $5-20.6,2-3.3$ & $7.5-9,8.5-12,24$ \\
\hline St. Gervais 2 & 7 th & $15-18$ & $7-26,2.5-4$ & $\begin{array}{c}11-18.5,16-33.5 \\
25.3\end{array}$ \\
\hline Dor 2006 & $\begin{array}{c}\text { Mid-6th- } \\
\text { beginning of } \\
\text { 7th }\end{array}$ & 25 & $7.5-22.7,2-4$ & $6.5-25,6.4-48,24$ \\
\hline Yassiada I & 625 & 20.52 & $13-25,3.5-4.2$ & $14,14,30-35$ \\
\hline $\begin{array}{l}\text { Pantano } \\
\text { Longarini }\end{array}$ & Early 7th & 31.5 & $14-54,5$ & $18-25,18-25,35$ \\
\hline Tantura F & $\begin{array}{l}\text { Mid-7th-end } \\
\text { 8th }\end{array}$ & 15.7 & $8-23.5,2.5$ & $9.5,12,31.5$ \\
\hline Tantura E & 7th-9th & 12.5 & $10-21,2.2-2.8$ & $10,12,26$ \\
\hline $\begin{array}{c}\text { Ma'agan } \\
\text { Mikhael B }\end{array}$ & 7th-9th & 20 & $12-23,3$ & $12,12,44$ \\
\hline Tantura B & $\begin{array}{c}\text { Beginning of } \\
\text { 9th }\end{array}$ & $18-23$ & $4-36,3$ & $9.2,9.4,26$ \\
\hline Bozburun & 874 & 14.3 & $3-4,4$ & $12-17,14-22,30-40$ \\
\hline
\end{tabular}

\section{Conclusions}

Based on the archaeological remains, it is suggested that the Ma'agan Mikhael B ship was originally at least $20 \mathrm{~m}$ long. Preliminary dating places the shipwreck in the 7th-9th centuries AD. The ship carried a cargo of amphorae, apparently, she was a merchantman plying the Levant coast. The on-going research of the shipwreck 
is contributing meaningful information on its hull and artefacts, adding to the existing corpus of shipwrecks in Late Antiquity, and to the study of the transition in ship construction.

\section{Acknowledgments}

The underwater excavations (IAA permits G-41/2016 and G-40/2017) and research of the Ma'agan Mikhael B shipwreck are supported by the Israel Science Foundation (grant no. 1891/16), the Honor Frost Foundation, a Dov Shafir Fellowship, a Natan Rotenstreich Scholarship, a Sir Maurice Hatter Fellowship, the Research Authority of the University of Haifa, and anonymous donors, to all of whom the authors are grateful. The authors would also like to thank J.B. Tresman for the English editing, and the Ma'agan Mikhael B dive team.

\section{References}

Barkai, O. and Kahanov, Y., 2016, The Tantura F shipwreck: hull remains and finds - final report. International Journal of Nautical Archaeology 45.1, 6-28.

Cvikel, D., Grøn, O. and Boldreel, O. L., 2017, Detecting the Ma'agan Mikhael B shipwreck. Underwater Technology 34.2, 93-8.

De Zeeuw, H. C., 1967, Wood, in Baumeister, T. and Marks, L. S. (eds.). Standard Handbook for Mechanical Engineers, 150-69. Tokyo. (7th edition)

Greenhill, B., 1957, The boats of Pakistan: a preliminary study. Mariner's Mirror 43.2, 106-34.

Kahanov, Y., 2011, Ship reconstruction, documentation, and in situ recording, in Catambis, A., Ford, B. and Hamilton, D. (eds.). Oxford Handbook of Maritime Archaeology, 161-181. Oxford.

Linder, E., 2003, The Discovery and preliminary exploration of the site, in Linder, E. and Kahanov, Y. The Ma'agan Mikhael Ship. The Recovery of a 2400-Year-Old Merchantman. Final Report, Volume I, 3-7. Jerusalem.

Pomey, P., Kahanov, Y. and Rieth, E., 2012, Transition from shell to skeleton in ancient Mediterranean shipconstruction: analysis, problems, and future research. International Journal of Nautical Archaeology 41.2, $235-314$

Steffy, J. R., 1994, Wooden Shipbuilding and the Interpretation of Shipwrecks. College Station. 
Ward, C., 2004, Plant Remains, in Bass, G. F., Matthews, S. D., Steffy, J. R. and van Doorninck, F. H. (eds.). Serçe Limani: An Eleventh-Century Shipwreck, I: The Ship and Its Anchorage, Crew, and Passengers, 496511. College Station. 